\title{
Training and Knowledge of Health Professionals about Hospital Waste and its Risks in a Central Hospital
}

Formação e Conhecimento dos profissionais de saúde sobre Resíduos Hospitalares e seus Riscos num Hospital Central

\author{
Beatriz Edra ${ }^{1,3}$, Bruno Magalhães ${ }^{1}$, Catarina Maia ${ }^{2}$, Filomena Cardoso ${ }^{2}$, José Manuel Silva1 and Maria do \\ Céu Costa ${ }^{3}$ \\ ${ }^{1}$ Escola Superior de Saúde de Santa Maria, Travessa Antero Quental n ${ }^{\circ} 173 / 175$, Porto, Portugal \\ ${ }^{2}$ Centro Hospitalar de São João, Alameda Prof. Hernâni Monteiro, 4200-319 Porto, Portugal \\ 4049-024 Porto, Portugal \\ ${ }^{3}$ CBIOS, Escola de Ciências e Tecnologias da Saúde, Universidade Lusófona, Campo Grande 376,1649-024 Lisboa, \\ Portugal \\ e-mail: beatriz.edra@santamariasaude.pt
}

\begin{abstract}
The knowledge retention and application after training / awarness of health professionals for the management of Hospital Waste (HW) is a demanding Key Performance Indicator (KPI) for the waste management process to be the most effective and efficient. This study presents the data about the frequency of training sessions / awarness by the professionals of a Central Hospital, the approach to the risks inherent to health and the environment, as well as the knowledge perceived by the trainees. It was concluded that although most of the professionals have training in the area with the coverage of the themes related to the risks inherent to HW, they recognize that their knowledge is insufficient.
\end{abstract}

Keywords: Hospital waste, Training, Risks to Health and Environment, Knowledge

\section{Resumo}

A retenção de conhecimento e sua aplicação após formação/sensibilização dos profissionais de saúde na gestão dos Resíduos Hospitalares (RH) é um Indicador de Desempenho Fundamental (KPI- Key Performance Indicator) para que o processo de gestão seja o mais eficaz e eficiente. Neste estudo apresentam-se os dados relativos à frequência de sessões de formação/sensibilização por parte dos profissionais de um Hospital Central, e à abordagem dos riscos inerentes à saúde e ambiente nas mesmas, bem como do conhecimento percecionado pelos formandos. Concluiuse que apesar da maioria dos profissionais ter formação na área com a abrangência das temáticas relativas aos riscos inerentes aos $\mathrm{RH}$, reconhecem que o seu conhecimento é insuficiente.

Palavras-chave: Resíduos Hospitalares, Formação, Riscos para a Saúde e Ambiente, Conhecimento. 


\section{Introduction}

The existence of training related to Hospital Waste (HW) and the waste management process in health units is fundamental in order to provide professionals with specific knowledge, minimizing the risks inherent to health and the environment (1).

There are several guidelines published by the Directorate General for Health in the area of organizational quality, which recommend the implementation of a set of good practices with a consecutive impact on infection control (BPIC - Basic Precautions for Infection Control) and financial impact reduction. $(2,3,4)$

It is appropriate to integrate the specific training plan in the area of Hospital Waste Management into the institutional training plan (5). Training in this area should take into account the determined training needs and should be adequate to the functional content of the different professional groups $(6,7)$.

For a study in this context, the HCSJ (Hospital Center of S. João) was selected based on its size and differentiation of the clinical practice. In addition to clinical excellence, the HCSJ recognizes the relevance to the simultaneous placement of Good Practices in terms of Corporate Governance. This high level of differentiation and quality of the HCSJ is perceived by the citizens, a fact that was once again confirmed in 2015 with distinction of the mark "Hospital Center of São João" as being the one with the highest spontaneous reputation among the facilities in the category of Hospitals and Health Clinics (8). The present research intends to identify the training held by the different professional groups and the contribution of this knowledge relative to the risk perception of the various HW groups.

\section{Methodology}

To achieve these objectives, a cross-sectional observational, descriptive, and correlational study was carried out, using a previously validated questionnaire as a data collection instrument that was applied to a sample of 1800 professionals from the clinical area. The response rate was $44 \%$, with 789 duly validated surveys of the various professional groups of 31 health unit CHSJ services, corresponding to a maximum error of $3.1 \%$ (considering a simple random sample without replacement for a confidence level of $95 \%$ ).

\section{Introdução}

A existência de formação nas unidades de saúde relativa ao processo de gestão de Resíduos Hospitalares é fundamental de forma a dotar os profissionais de conhecimento específico, minimizando os riscos inerentes à saúde e ambiente (1).

Existem diversas normas orientadoras na área da qualidade organizacional, publicadas pela Direção-Geral de Saúde, que recomendam a implementação de um conjunto de boas práticas com impacto consecutivo no controlo da infeção (PBCI - Precauções Básicos do Controlo da Infeção) e na redução do impacto financeiro. $(2,3,4)$

Torna-se pertinente integrar o plano de formação específico na área de gestão de Resíduos Hospitalares (RH) no plano de formação institucional (5). As formações nesta área devem atender ao levantamento das necessidades de formação diagnosticadas, devendo ser adequadas ao conteúdo funcional dos diferentes grupos profissionais $(6,7)$.

Para um estudo neste contexto selecionou-se o CHSJ (Centro Hospitalar de S.João) tendo por base a sua dimensão e diferenciação da prática clinica. Para além da excelência clínica, o CHSJ reconhece a relevância na aposta simultânea ao nível das Boas Práticas em termos de Governo Societário. Este elevado nível de diferenciação e qualidade do CHSJ é percecionado pelos cidadãos, facto que foi uma vez mais confirmado em 2015 com distinção da marca "Centro Hospitalar de São João" como sendo aquela que detém o maior índice de notoriedade espontânea de entre as marcas de saúde mais conceituadas do país na categoria de Hospitais e Clínicas de Saúde (8).

Assim, com a presente investigação pretende-se identificar a formação detida, pelos diferentes grupos profissionais, e qual o contributo desse conhecimento relativo à perceção de risco dos diversos grupos de resíduos hospitalares.

\section{Metodologia}

Para a concretização destes objetivos desenhou-se um estudo observacional, descritivo e correlacional de caráter transversal, utilizando como instrumento de recolha de informação um questionário (já validado) que foi aplicado a uma amostra de 1800 profissionais da área clínica, dos quais se obteve uma taxa de resposta de 44\%, com 789 inquéritos devidamente validados dos diversos grupos profissionais de 31 serviços da unidade de saúde CHSJ, que corresponde a um erro máximo de $3,1 \%$ (considerando uma amostra aleatória simples sem 
The data presented here relate only to a part of all the data collected by the application of the questionnaire. Those who answered the following questions were selected:

Question 1 - Have you had any type of training / awareness of Hospital Waste here in the Hospital?

Question 2 - If yes, in some of these formations, were the risks associated with health and environment covered?

Question 3 - Do you consider your knowledge about the risks associated with hospital waste to be sufficient? The data were analysed using descriptive and inferential statistics, using the IBM SPSS 23.0 software. The existence of differences in the packaging of hospital wastes between those who had and who did not have waste training / awarness were investigated using the homogeneity test of the proportions (chi-square test) or, when the number of observations was reduced, to Fisher's exact test.

\section{Results and discussion}

Of the 1800 questionnaires distributed, 789 professionals answered, corresponding to a sample composed of 580 nurses, 132 medical assistants and 77 doctors, of several services, with the three most representative being Urgency (10.3\%), Internal Medicine (9.6\%), and Pediatrics hospitalization (6\%).

Table I shows the frequency (total and for each profession) of the professionals who had some form of hospital waste training within the hospital. Most of the professionals had training (55.9\%). There are differences between the three professions regarding training in this area, with the medical professional class being found to have less training in the area (18.2\%), followed by nurses $(58.4 \%)$ and medical assistants with higher education $(66.7 \%)$.

Of the professionals who answered affirmatively to Question 1 (Table 2), most (76\%), confirmed, that the training covered the risks associated with health and the environment. The distribution of the answers of the three professions was compared, using the homogeneity of proportions test for doctors (10 doctors or 71.4\%), for nurses (250 nurses or $73.7 \%$ ) and for medical reposição para um nível de confiança de 95\%).

Para seleção da amostra, foram selecionados os serviços de área clínica tendo por base etiologia das funções dos serviços, nomeadamente relacionados com o tipo de cuidados prestados, o que conduz a uma potencialidade de maior produção de diferentes resíduos hospitalares, bem como em relação a produção de RH apresentados nos dois últimos anos.

Os dados aqui apresentados, dizem apenas respeito a uma parte de todos os dados recolhidos pela aplicação de questionário. Selecionaram-se aqueles que dariam resposta às seguintes questões:

Questão 1 - Já teve algum tipo de formação/sensibilização de Resíduos Hospitalares aqui no Hospital?

Questão 2 - Se sim, em algumas dessas formações, os riscos associados à saúde e ambiente foram abrangidos? Questão 3 - Considera suficiente o conhecimento que possui sobre riscos associados aos resíduos hospitalares?

Os dados foram tratados com recurso à estatística descritiva e inferencial, recorrendo ao software IBM SPSS 23.0. Pesquisou-se a existência de diferenças no acondicionamento dos resíduos entre quem teve e quem não teve formação/sensibilização dos resíduos, recorrendo-se ao teste da homogeneidade das proporções (teste do qui-quadrado) ou, quando o número de observações era reduzido, ao teste exato de Fisher.

\section{Resultados e discussão de dados}

Dos 1800 questionários distribuídos, responderam 789 profissionais, correspondente a uma amostra composta por 580 enfermeiros, 132 auxiliares de ação médica e 77 médicos, de vários serviços, sendo os três mais representativos o serviço de Urgência (10,3\%), a Medicina interna $(9,6 \%)$ e a Pediatria internamento $(6 \%)$. A tabela I mostra a frequência (total e para cada profissão) dos profissionais que tiveram algum tipo de formação de resíduos hospitalares no hospital. A maior parte dos profissionais, 55,9 \%, teve formação (55,9\%). Existem diferenças entre as três profissões no que diz respeito a formação nesta área, sendo a classe profissional médico a que refere ter menos formação na área $(18,2 \%)$, seguido dos enfermeiros $(58,4 \%)$ e os auxiliares de ação médica com maior formação $(66,7 \%)$.

Os profissionais que responderam afirmativamente à questão 1 (Tabela 2), confirmaram na sua maioria, 76\%, que as formações abrangeram os riscos associados à saúde e ao ambiente.

Comparou-se a distribuição das respostas das três profissões, recorrendo-se ao teste da homogeneidade das proporções para os médicos (10 médicos ou 71,4\%), 
assistants (75 medical assistant or 85.2\%).

The statistic test chi-square (of 2 degrees of freedom) is 7.9 ( $p<0.01)$, so it is concluded that there are differences in the proportions of affirmative answers of the three professions. Due to the reduced number of physicians with negative response, Fisher's test $(p<0.01)$, very similar to the chi-square test, was also performed. In order to compare the occupations, the homogeneity of proportions test was again used, adjusting the level of significance by the Bonferroni correction that results in an adjusted level of significance in $5 \% / 3 \approx 1.67 \%$. To compare doctors with nurses, doctors with medical assistants and nurses with medical assistants, test statistics (chi-square of 1 degree of freedom) and p-values are respectively $p=1, p=0.420$ and $p<0.01$. Therefore, it can be concluded that the proportion of nurses who answered affirmatively is lower than that of the medical assistants, and no other significant difference was found (Fisher exact test to compare doctors with other professions led to p-values of approximately 1 and 0.201 , respectively, for nurses and medical assistants, maintaining the chi-square test conclusions). para os enfermeiros (250 enfermeiros ou 73,7\%) e para os auxiliares de ação médica (75 auxiliares ou 85,2\%). A estatística do teste qui-quadrado (de 2 graus de liberdade) é $7,9(\mathrm{p}<0,01)$, pelo que se conclui que existem diferenças nas proporções de respostas afirmativas das três profissões (devido ao reduzido número de médicos com resposta negativa, Bonferroni, efetuou-se também o teste de Fisher $(\mathrm{p}<0,01)$, muito semelhante ao do teste do qui-quadrado). Para comparar as profissões, recorre-se novamente ao teste de homogeneidade das proporções, ajustando-se o nível de significância pela correção de Bonferroni de que resulta um nível de significância ajustado de $5 \% / 3 \approx 1 . \varnothing \%$

Assim para comparar os médicos com os enfermeiros, os médicos com os auxiliares de ação médica e os enfermeiros com os auxiliares de ação médica, as estatísticas de teste (qui-quadrado de 1 grau de liberdade) e os valores-p são respetivamente, $p=1, p=0.420$ e $p<0.01$, pelo que se conclui que a proporção de enfermeiros que responderam afirmativamente é inferior à dos auxiliares de ação médica, não se encontrando nenhuma outra diferença significativa. Refira-se que o teste exato de Fisher para comparar os médicos com as outras profissões conduziu aos valores-p de aproximadamente $1 \mathrm{e}$ de 0.201 respetivamente para enfermeiros e auxiliares de ação médica, mantendo as conclusões do teste do qui-quadrado.

Table 1/ Table 1 - Participation of training / awerness in the area of Hospital Waste by health professionals/ (Answer to the question: Have you had any type of training / awareness of Hospital Waste here in the Hospital?)

Participação na formação/sensibilização na área dos RH por parte dos profissionais de saúde (Resposta à questão: Já teve algum tipo de formação/sensibilização de Resíduos Hospitalares aqui no Hospital?)

\begin{tabular}{lcccccc} 
& \multicolumn{2}{c}{ Yes/ Sim } & \multicolumn{2}{c}{ No/ Não } & \multicolumn{2}{c}{ N.A./ N.R. } \\
\cline { 2 - 7 } & $\mathrm{N}$ & $\%$ & $\mathrm{~N}$ & $\%$ & $\mathrm{~N}$ & $\%$ \\
\hline $\begin{array}{l}\text { Training / awareness } \\
\text { Formação/sensibilização }\end{array}$ & 441 & 55.9 & 312 & 39.5 & 36 & 4.6 \\
\hline Doctor/ Médico/a & 14 & 18.2 & 59 & 76.6 & 4 & 5.2 \\
\hline Nurse/ Enfermeiro/a & 339 & 58.4 & 214 & 36.9 & 27 & 4.7 \\
\hline $\begin{array}{l}\text { Medical Assistant/ Auxiliar de } \\
\text { ação médica }\end{array}$ & 88 & 66.7 & 39 & 29.5 & 5 & 3.8 \\
\hline
\end{tabular}


Table 2/ Tabela 2 - Approach to risks associated with health and the environment/ (Answer the question for those who report having had training: The risks were covered? Abordagem dos riscos associados à saúde e ambiente nas formações (Resposta à questão para os que referem ter tido formação: Os riscos foram abrangidos?

\begin{tabular}{lcccccc} 
& \multicolumn{2}{c}{ Yes/ Sim } & \multicolumn{2}{c}{ No/ Não } & \multicolumn{2}{c}{ N.A./ N. R. } \\
\cline { 2 - 7 } & $\mathrm{N}$ & $\%$ & $\mathrm{~N}$ & $\%$ & $\mathrm{~N}$ & $\%$ \\
\hline $\begin{array}{l}\text { Risk approach/ Abordagem dos } \\
\text { riscos }\end{array}$ & 335 & 76.0 & 95 & 21.5 & 11 & 2.5 \\
\hline Doctor/ Médico/a & 10 & 71.4 & 3 & 21.4 & 1 & 7.1 \\
\hline Nurse/ Enfermeiro/a & 250 & 73.7 & 83 & 24.5 & 6 & 1.8 \\
\hline $\begin{array}{l}\text { Medical Assistant/ Auxiliar de } \\
\text { ação médica }\end{array}$ & 75 & 85.2 & 9 & 10.2 & 4 & 4.5 \\
\hline
\end{tabular}

Regarding Question 2, Table 3 shows the frequency (total and for each profession) of the professionals' opinion on whether they consider that their knowledge about the risks associated with hospital waste is sufficient. Only a minority of professionals consider that their knowledge about the risks associated with hospital waste is sufficient (252 professionals or $31.9 \%$ ), for doctors (19 doctors or 24.7\%), nurses (184 nurses or $31.7 \%$ ), and for medical assistants (49 auxiliaries or $37.1 \%)$.

To compare the distribution of the answers of the three professions, the homogeneity of proportions test was used. The test statistic (chi-square of 2 degrees of freedom) is $3.7(p=0.157)$, so it is not possible to state that there are differences in the proportions of professionals in the three professions who consider that the knowledge they possess regarding risks is sufficient associated with hospital waste.

Compared to a study carried out in public and private hospitals in the Algarve (9), it was verified that, as in the present study, the highest percentage of public hospital respondents admits having participated in training actions. The results of the two public and private sector respondents did not show significant differences (9), although a higher percentage of public hospital respondents admitted having participated in training actions, which may be related to the size of the institution and the importance given to the management of HW. In private hospitals, a higher percentage of health professionals indicated that the risks associated with HW were addressed in the training in which they participated. In the present study, more than 58\% (58.3\% - 71.4\%)
Relativamente à questão 2 , a tabela 3 , mostra a frequência (total e para cada profissão) da opinião dos profissionais sobre se consideram que é suficiente o conhecimento que possuem relativo aos riscos associados aos resíduos hospitalares. Apenas uma minoria dos profissionais considera que os conhecimentos que possui sobre os riscos associados aos resíduos hospitalares são suficientes (252 profissionais ou 31,9\%), sendo para os médicos (19 médicos ou 24,7\%), para os enfermeiros (184 enfermeiros ou $31,7 \%$ ) e para os auxiliares de ação médica (49 auxiliares ou 37,1\%).

Para comparar a distribuição das respostas das três profissões, recorreu-se ao teste da homogeneidade das proporções. A estatística do teste (qui-quadrado de 2 graus de liberdade) é $3,7(p=0,157)$, pelo que não é possível afirmar que existam diferenças nas proporções de profissionais das três profissões que consideram que é suficiente o conhecimento que possuem relativo aos riscos associados aos resíduos hospitalares.

Em comparação com um estudo realizado em hospitais públicos e privados do Algarve (9), verifica-se que tal como no presente estudo, a maior percentagem de inquiridos do hospital público admite ter participado em ações de formação. Os resultados dos inquiridos dos dois sectores, público e privado, não apresentam diferenças significativas, embora maior percentagem de inquiridos do hospital público admita ter participado em ações de formação, o que pode estar relacionado com a dimensão da instituição e da importância dada à gestão de RH. Foi nos hospitais privados que os profissionais de saúde admitem em maior percentagem que os riscos associados aos RH foram abordados nas formações 
of the respondents in any of the professional categories consider that their knowledge about the risks associated with HW is not enough. Hence, it is recommended that Strategic Management Plans of Hospital organizations would include KPI dedicated to training activities. It may be a KPI on Knowledge Retention and Applicability, or a KPI on Operational Effectiveness Measures and /or a KPI on Learner Satisfaction. Indeed, preand post-training testing provides a good indicator of training effectiveness. Testing before training provides a baseline of knowledge and shows knowledge gaps. Post-training testing scores should demonstrate improvement in knowledge and show the degree to which participants learned the relevant subjects. In order to identify how much knowledge attendants retain over time, offering a second post-training test several weeks following the training should be considered. This can further demonstrate the effectiveness of training. As far as operational effectiveness pertains to the ability to link training objectives back to strategic business goals, the effectiveness of a skill related to training to improve that particular skill should be related back to specific business goals. Additionally, if training seeks to address performance gaps, the training KPIs should include operational metrics such as deadlines missed, waste handling and management errors, accident records, etc. to determine if training helped to increase competencies in key operational areas. Finally, some of the best insights can be gleamed by asking the trainees themselves for their perceptions of the training. Upon conclusion of a training event, the learners opinions of the training should always be asked, what they liked, disliked and which skills could be improved for waste management. em que participaram.

No presente estudo verifica-se que, em qualquer das categorias profissionais, mais de 58\% $(58,3 \%-71,4 \%)$ dos inquiridos considera que o conhecimento que possuiu sobre os riscos associados aos RH não é suficiente. Portanto, recomenda-se que os Planos de Gestão Estratégica das organizações hospitalares incluam indicadores de desempenho (KPI) dedicado às atividades de formação. Poderá ser um KPI sobre Retenção de Conhecimento e Aplicabilidade, ou um KPI sobre Medidas de Eficácia Operacional e / ou um KPI sobre Satisfação do Formando. De facto, os testes pré e pós-formação fornecem um bom indicador da eficácia da formação. Testes antes da formação fornecem uma base de conhecimento prévio e mostram lacunas de conhecimento. As pontuações dos testes pós-treino devem demonstrar melhorias no conhecimento e mostrar o grau em que os participantes aprenderam o que era mais relevante. Para identificar quanto conhecimento os participantes retêm ao longo do tempo, deve ser realizado um segundo teste pós-formação várias semanas após o treino. Isso pode demonstrar ainda mais a eficácia da formação. No que diz respeito à eficácia operacional relacionada com a capacidade de vincular os objetivos de formação aos objetivos de negócios estratégicos, a eficácia de uma competência adquirida relacionada com uma ação de formação para melhorar essa competência específica poderá estar estrategicamente relacionada com metas específicas do plano estratégico/ de negócios. Além disso, se uma formação procurar resolver as deficiências de desempenho, os KPIs de formação devem incluir métricas operacionais como prazos perdidos, erros de manuseamento e gestão dos resíduos, registos de acidentes etc. para determinar se a formação ajudou a aumentar as competências nas principais áreas operacionais. Finalmente, alguns dos melhores indicadores podem ser vislumbrados perguntando aos próprios formandos as suas perceções sobre a formação. Após a conclusão de um evento de formação, as opiniões dos participantes sobre a formação devem sempre ser avaliadas, o que gostaram, não gostaram e quais as informações que podem ser melhoradas para uma gestão eficaz e eficiente de resíduos. 
Table 3/ Tabela 3 - Perceived knowledge on the risks associated with hospital waste by professionals/ Answer to the question: Do you consider your knowledge of the risks associated with hospital waste to be sufficient?

Conhecimento percecionado sobre os riscos associados aos resíduos hospitalares por parte dos profissionais (Resposta à questão: Considera suficiente o conhecimento que possui sobre riscos associados aos resíduos hospitalares?)

\begin{tabular}{lcccccc} 
& \multicolumn{2}{c}{ Yes/ Sim } & \multicolumn{2}{c}{ No/ Não } & \multicolumn{2}{c}{ N.W./ N.R. } \\
\cline { 2 - 7 } & $\mathrm{N}$ & $\%$ & $\mathrm{~N}$ & $\%$ & $\mathrm{~N}$ & $\%$ \\
\hline $\begin{array}{l}\text { Risk approach/ Abordagem dos } \\
\text { riscos }\end{array}$ & 252 & 31.9 & 502 & 63.6 & 35 & 4.4 \\
\hline $\begin{array}{l}\text { Doctor/ Médico/a } \\
\text { Nurse/ Enfermeiro/a }\end{array}$ & 19 & 24.7 & 55 & 71.4 & 3 & 3.9 \\
\hline $\begin{array}{l}\text { Medical Assistant/ Auxiliar de } \\
\text { ação médica }\end{array}$ & 49 & 37.1 & 77 & 58.3 & 6 & 4.5 \\
\hline
\end{tabular}

\section{Conclusion}

More than half of the group of 789 participating health professionals indicated they have had already had some type of training / sensitization about hospital waste in the hospital where they work. The risks associated with health and the environment were covered in most of the training for medical assistants (85.2\%) and for nurses (73.7\%). The risks associated with health and the environment were covered in some of the training, according to $71.4 \%$ of the doctors answers who had training in HW, but only $18.2 \%$ of this medical population (of 77 doctors) had participated in a training session . Consequently, a large proportion of doctors $(71.4 \%)$ consider the knowledge about the risks associated with HW to be insufficient. This figure is lower for nurses $(63.8 \%)$ and for medical assistants $(58.3 \%)$.

This study is in line with most of the published studies on HW management, concluding that there is a lack of data on specific interventions to evaluate the effectiveness of training on good HW management practices and that the efficiency of this process requires a combination of bottom-up solutions, such as training and training programs, and top-down strategies solutions $(10,11,12)$.

\section{Conclusões}

Mais de metade do conjunto de profissionais de saúde (789) já teve algum tipo de formação / sensibilização sobre resíduos hospitalares no Hospital onde exerce funções, tendo os riscos associados à saúde e ao ambiente sido abrangidos na maioria das formações dirigidas aos auxiliares de ação médica $(85,2 \%)$ e aos enfermeiros $(73,7 \%)$. Foram abrangidos os riscos associados à saúde e ao ambiente em alguma da formação de acordo com $71,4 \%$ dos médicos respondentes que tiveram formação sobre $\mathrm{RH}$, mas apenas $18,2 \%$ da população médica (77) teve acesso a esses conteúdos de formação. Consequentemente uma grande proporção dos médicos $(71,4 \%)$ considera não suficiente o conhecimento sobre os riscos associados aos RH sendo este número decrescente para os enfermeiros $(63,8 \%)$ e para os auxiliares de ação médica $(58,3 \%)$.

Este estudo está alinhado com a maioria dos estudos publicados, sobre gestão de RH, concluindo-se que há falta de dados sobre intervenções específicas, destinadas a avaliar a eficácia da formação sobre as boas práticas de gestão de $\mathrm{RH}$, e que a eficiência deste processo exige uma combinação de soluções bottom-up, como programas de formação e treino e soluções estratégias top-down $(10,11,12)$. 


\section{Acknowledgements}

The authors would like to express their gratitude to the Direction of the Hospital Center of S. João for the approval of the research project that underlies this work.

\section{Agradecimentos}

Os autores gostariam de expressar os seus agradecimentos à Direção do Centro Hospitalar de S. João pela aprovação do projeto de investigação subjacente a este trabalho.

\section{Conflitos de Interesses}

Os autores declaram que não tem qualquer relação de potencial conflito de interesses.
The authors declare that they do not have any type of relationship likely to have a potential conflict of interest.

\section{References/ Referências}

1 - Pinzone, M., Lettieri E., Masella C., (2015), Proactive Environmental Strategies in Healthcare Organisations: Drivers and Barriers in Italy, Journal of Bussiness Ethics, 2015, volume 131, pág. 83-197, acedido em janeiro 2016, disponível em: https://link.springer.com/article/10.1007/s10551-014-2275-8 2 - George F, Norma da Direção-Geral da Saúde, Precauções Básicas do Controlo da Infeção Nº29/2012, atualizada a 31/10/2013.

3 - Direção Geral de Saúde, Resíduos hospitalares - Documento de Orientação; Direcção Geral da Saúde, (2009), Divisão de Saúde Ambiental e Ocupacional, acedido em dezembro 2015, disponível em: https://www.dgs.pt/documentos-e-publicacoes/residuos-hospitalares.aspx

4- Porter, M.E, What is value in health care? N, Engl, J, Med, 2010, 363 (26), 477e2481.

5 - Neves R., Resíduos hospitalares - práticas e riscos. A influência da formação profissional nas práticas de gestão. Tecno hospital, 2013,55 , pp. 30-37.

6 - Thakur V, Ramesh A, Healthcare waste management research: A structured analysis and review 2005-2014, Waste Management \&Research, 2015; 1-16.

7- Chang $\mathrm{CH}$, Chiao YC, Tsai Y, Identifying competitive strategies to improve the performance of hospitals in a competitive environment, BMC Health Services Research, 2017, 17:756, acedido em janeiro 2108, disponivel em: https://bmchealthservres.biomedcentral.com/articles/10.1186/s12913-0172699-9

8- São João Distinguido com onze Centros de Referência (Acedido em .05/01/2017) in http://portal-chsj.min-saude.pt/pages/618in

9 - Ferreira V, Avaliação das Práticas de Gestão de Resíduos Hospitalares, Risco e Perceção de Risco Associado, Dissertação apresentada no Âmbito do Mestrado Integrado em Engenharia do Ambiente na área de Tecnologias Ambientais pela Universidade do Algarve. 2009, acedido em Dezembro 2015, disponível em: https://sapientia.ualg.pt/bitstream/10400.1/1738/1/Vera25026.pdf

10- Delmonico DVG, Santos HH, Pinheiro MAP, Castro R, Souza RM, Waste management barriers in developing country hospitals: Case study and AHP analysi, Waste Management \& Research,2017, Vol 36, Issue 1, pp. 48 - 58

11 - Harhay MO, Halpern SD, Harhay JS, et al., Health care waste management: A neglected and growing public health problem worldwide. Tropical Medicine \& International Health, 2009, 14: 1414-1417.

12- Oroei M, Momeni M, Palenik CJ, et al. A qualitative study of the causes of improper segregation of infectious waste at Nemazee Hospital, Shiraz, Iran. Journal of Infection and Public Health, 2014, 7: 192-198. 